\title{
The Effects of Perceived Ease of Use, Security, and Promotion on Trust and Its Implications on Fintech Adoption
}

\author{
Meryl Astin Nangin', Irma Rasita Gloria Barus², Soegeng Wahyoedi *)3 \\ ${ }^{1}$ Bank Central Asia, Jakarta \\ ${ }^{2}$ School of Vocational Studies, IPB University, Bogor, West Java \\ ${ }^{3}$ Faculty of Economics and Business, Krida Wacana Christian University, Jakarta \\ *Corresponding author: swahyoedi@ukrida.ac.id
}

\begin{abstract}
The advancement of mobile devices and their usage has increased the uptake of fintech innovation. These new technologies should provide ease of use and give advantages to their customers. On the other side, mobile application security threats have increased tremendously and have become a great challenge for both users, in this case, as customers, and fintech innovators. Meanwhile, service should be promoted to the customers to establish fintech's brand to society. This research empirically examined the components affecting the expectations of users to adopt fintech. By collecting 100 samples who have already used a couple of brands of Fintech and Sakuku as their payment method, and by utilizing Structural Equation Modeling- Partial Least Square (SEM-PLS) as the technique of analysis, the empirical results definitely confirmed that perceived ease of use (PEOU) and promotion positively and significantly affected the customer trust. Meanwhile, security did not significantly affect trust. The finding also implied that in order to increase the fintech adoption rate, customer trust should be built.
\end{abstract}

Keywords: Fintech, perceived ease of use, promotion, security, trust

\begin{abstract}
Abstrak
Kemajuan perangkat seluler dan penggunaannya telah meningkatkan penyerapan inovasi fintech. Teknologi baru ini harus memberikan kemudahan penggunaan dan memberikan keuntungan bagi pelanggannya. Di sisi lain, ancaman keamanan aplikasi seluler telah meningkat pesat dan menjadi tantangan besar bagi pengguna, dalam hal ini sebagai pelanggan, dan inovator fintech. Sementara itu, layanan harus dipromosikan kepada pelanggan untuk membangun brand fintech kepada masyarakat. Penelitian ini secara empiris mengkaji komponen-komponen yang mempengaruhi ekspektasi pengguna dalam mengadopsi fintech. Data diambil dengan mengumpulkan 100 responden yang telah menggunakan beberapa merek fintech dan Sakuku sebagai metode pembayarannya, serta dengan teknik analisisnya menggunakan model persamaan Structural-Partial Least Square (SEM-PLS) sebagai teknik analisis, hasil empiris yang diperoleh secara pasti menegaskan bahwa persepsi kemudahan penggunaan (PEOU) dan promosi berpengaruh
\end{abstract}


positif dan signifikan terhadap kepercayaan pelanggan. Sebaliknya, keamanan tidak berpengaruh signifikan terhadap trust. Temuan tersebut juga menyiratkan bahwa untuk meningkatkan tingkat adopsi fintech, kepercayaan pelanggan harus dibangun.

Kata kunci: fintech, persepsi kemudahan penggunaan, promosi, keamanan, kepercayaan

\section{Introduction}

The digital age has infiltrated all lines of life in all parts of the world while changing the way humans interact socially and carry out economic activities. Banking and payment instrument domains have also changed from cash-based to non-cash based. The electronic payment system in Indonesia continues to transform following the needs of the community and e-commerce business. Technology adoption in all fields, including banking, is a necessity. The world's policymakers assess that banks that do not adopt technology or switch to digital will gradually be replaced. One of the industries that can replace the role of banks is a financial technology (Fintech).

Technological developments adopted for financial technology activities (Fintech) play an important role as a booster in maximizing, changing, accelerating, and sharpening various aspects of financial services that are currently available, ranging from payment methods, fund transfers, loans, fund collection, to asset management. Fintech is becoming a global phenomenon, led by innovators and followed closely by academics, and now drawing the attention of regulators. In general, fintech is an umbrella term for innovative technology-enabled financial services and business models that accompany those services. In simpler terms, fintech can be used to describe any innovation that relates to how businesses seek to improve the process, delivery, and use of financial services (Mention, 2019).

Fost (2020) on in his research on the use of fintech in several countries, especially in developing countries, found that fintech adoption is driven by the unmet demand for financial services, and adopting fintech will provide greater financial inclusion. In other countries, fintech adoption is associated with the high cost of traditional finance, a supportive regulatory environment, and other factors, especially macroeconomy. Meanwhile, demographic factors also play an important role because there is a tendency for the young age group to trust and adopt fintech services. Fintech adoption can help make the financial system more inclusive and efficient, which in turn can provide economic benefits.

According to Hsu and Lin (2015), user intention to purchase technology innovation, or in the context of this research is fintech adoption or the use of brand fintech by users, can be measured by how feasible a product is, so users feel they will use it frequently and recommend the product to others. The growth of Fintech in Indonesia has received direct supports and full monitoring from the government, Bank Indonesia, and the Financial Services Authority (OJK), where the regulators expect that these companies could increase financial inclusion in Indonesia.

Efforts to increase financial inclusion are intended to reach people of working age who have not yet used financial services such as transaction, payments, moneysaving, credit, or insurance services (unbanked people) to obtain those accesses/services, both formal and informal services (Bank Indonesia, 2018). Bank Indonesia conducted various studies in which the increase in Indonesia's financial inclusion makes the economic turnover faster and more effective so that economic 
growth in Indonesia will also be more advanced. Fintech comes as an answer to facilitate the public in accessing financial products and simplify the transaction process. Due to the ease and speed offered, fintech has become very popular among millennials and is predicted to continue growing. Perceived ease of use of technology is defined as

a measure by which someone believes that technological devices can be easily understood and used. The frequency of use and interaction between the user and the system is also able to show the system's ease of use. The more commonly used system shows that the system is better known and easier to operate and use by its users (Chau, \& Lai, 2003).

Bank Indonesia recorded that the total transaction volume in the fintech market continued to increase. In 2017, the total volume of fintech market transactions reached US $\$ 18.65$ billion, or equivalent to $\mathrm{Rp} 251.78$ trillion. This figure grew by $24.6 \%$ compared to the previous year. Morgan Stanley AlphaWise further stated that in 2027, the development of Fintech in Indonesia is predicted to reach US\$50 billion, or equivalent to around $\mathrm{Rp} 700$ trillion. The growth trend of the fintech industry is a big opportunity with an appeal not only for start-ups but also for banks in Indonesia competing to produce new fintech brands to take part in business opportunities in Indonesia.

Looking at the vast number of competitors in the field of Fintech in Indonesia, a product that has an effective marketing mix will greatly affect the success of a brand. Likewise, in fintech adoption, the amount of transaction values in the Indonesian fintech market is greatly affected by the promotion strategy of each fintech brand in Indonesia. According to Tariq (2014), promotions are a means for companies to communicate with customers. Subsequently, advertisements and discounts from various fintech brands are often found in various shopping centers.

Bank $\mathrm{X}$ as the largest private bank in Indonesia with more than 19 million worth of customer savings accounts, refuses to lag behind in developing its business. Bank X, whose customers are mostly from "Gen Y" or millennial generation (a group of people with an initial birth year of the 1980s), is continuously striving to provide complete banking products and solutions for customers who need to carry out various transactions with just the touch of a finger on a mobile screen, so there is no need to come to the bank to conduct financial transactions, with guaranteed security. At the end of 2015, Bank X added a new product portfolio, namely Sakuku, to answer the needs of the young generation. Sakuku is electronic money that can be used for payments, shopping, topping up, and other banking transactions, which are still being developed by Bank X. Sakuku is also the first Fintech in Indonesia to use a Q.R. code scan as a means of payment.

Even though Bank X is the largest private bank in Indonesia, Morgan Stanley's research, entitled Indonesia Banks: Fintech Continues to Lead Digital Payment, reveals that digital transactions in Indonesia are dominated by financial technology companies that are newer than banks. GO-PAY (launched in 2016) and OVO (launched in 2017) are the two main players that the public prefers (Tri, 2019). Judging from the number of users, reported by MDI Venture, Sakuku users have not even reached 500 thousand users, while $G O-P A Y$ has reached more than 10 million users, and OVO has reached 7 million users (Agusta, 2018). From all the data presented above, examining aspects that need to be improved by $S a k u k u$ becomes a very interesting object, considering that this product was launched by the largest private bank in Indonesia. 
In regards to technology for conducting financial transactions, data security is highly important (Stewart \& Jürjens, 2018). Along with technology development, data security must also be tightened to avoid data misuse (cybercrime). According to Widiastuti (2018) quoted the survey results of the Indonesian Internet Service Providers Association (APJII), stating that $71 \%$ of respondents claimed to be concerned about online banking fraud, while $48 \%$ were concerned about the vulnerability of online financial transactions to cyber-fraud because the security level was considered low.

This contrasts with the growth rate of Fintech in Indonesia previously discussed. This means that even though the risk has been realized by the public, it does not necessarily make people stop using fintech. The decision to use it for financial transactions is strongly determined by the level of customer trust (Stewart \& Jürjens, 2018). Therefore, the key to the success of internet-based financial transactions is built from a trusted transaction process in which businesses must create an atmosphere that is able to make potential customers feel comfortable and confident to make transactions via the internet (Grabosky, Duffield \& Graycar, 2001).

Based on the results of APJII research in 2017, 143.26 million people in Indonesia have used the internet. However, the Indonesian Fintech Association (AFTECH) states that $69 \%$ of smartphone users have not used Fintech (Pryanka, 2018). For this reason, one of the objectives of this research is to identify variables to be developed by a fintech brand, in this case, Sakuku, so that it can take a greater part in Indonesia's fintech portfolio development.

One variable that affects a system to be accepted or not is perceived ease of use, examined initially by Davis (1989). Perceived ease of use is defined as the extent to which users believe that using an application is free of effort. An application that is felt to be easier to use than others will be more easily accepted by users (Widyastuti \& Anggraeni, 2017). If an application is found difficult to utilize, then the application will no longer be used by customers. Generally, a system that is easier to use eventually becomes more useful for its users (Anjelina, 2018; Heryani, Simanjuntak \& Maulana, 2020). Other than that, security covers the concept of administering personal data of fintech users, which includes maintaining confidentiality and providing confidence in security guarantees (Abdullatif, Purnaningsih \& Simanjuntak, 2020). In a condition where there is an element of uncertainty, it automatically carries risks; in risky conditions, trust is required so that the parties involved are willing to take action (Raman \& Annamalai, 2011).

The research problems were formulated as follows: (1) Does the ease of using fintech affect customer trust in fintech? (2) Does data security affect customer trust in fintech? (3) Does the promotion affect customer trust in fintech? (4) Does customer trust in fintech affect customer decisions to use fintech (fintech adoption)?.

\section{Methods}

\section{Participant}

This is a survey research using a questionnaire instrument. One hundred samples were taken as samples from the population of Sakuku fintech users in Jakarta. The respondents were chosen simply randomly from users of Sakuku located in Jakarta. This research was exploratory causality research aiming to find an explanation in the form of 
cause and effect relationships between several concepts or variables developed in the research through hypothesis testing.

\section{Measurement}

The construct of PEOU variable was measured using five indicators (items), the construct of Security variable was measured using three indicators (items), the construct of Promotion variable was measured using four indicators (items), while the construct of Trust variable was measured using five indicators (Items), and Fintech Adoption variable was measured using three indicators (items). Fintech, or financial technology, is a financial service based on new technology and is an innovation presented to replace conventional financial transaction methods. The technology is presented to provide comfort to the community in this modern era (Wankhede \& Salunkhe, 2018). The indicator or item was then tested for validity using discriminant validity with a measure of loading indicator value $>0.7$ and AVE value $>0.5$. Indicators were also tested for reliability using Cronbach's alpha values and composite reliability > 0.7 (Hair, 2014).

\section{Analysis}

The data were analyzed using Structural Equation Modeling - Partial Least Square (SEM-PLS) through SmartPLS tool/software (v.3.2.8). This analysis technique is a combination of two disciplinary methodologies: the econometric perspective focusing on predictions and psychometrics that are able to describe the model concept with latent variables (variables that cannot be measured directly) but were measured through the indicators (Wahyoedi, 2017). The research model can be seen below:

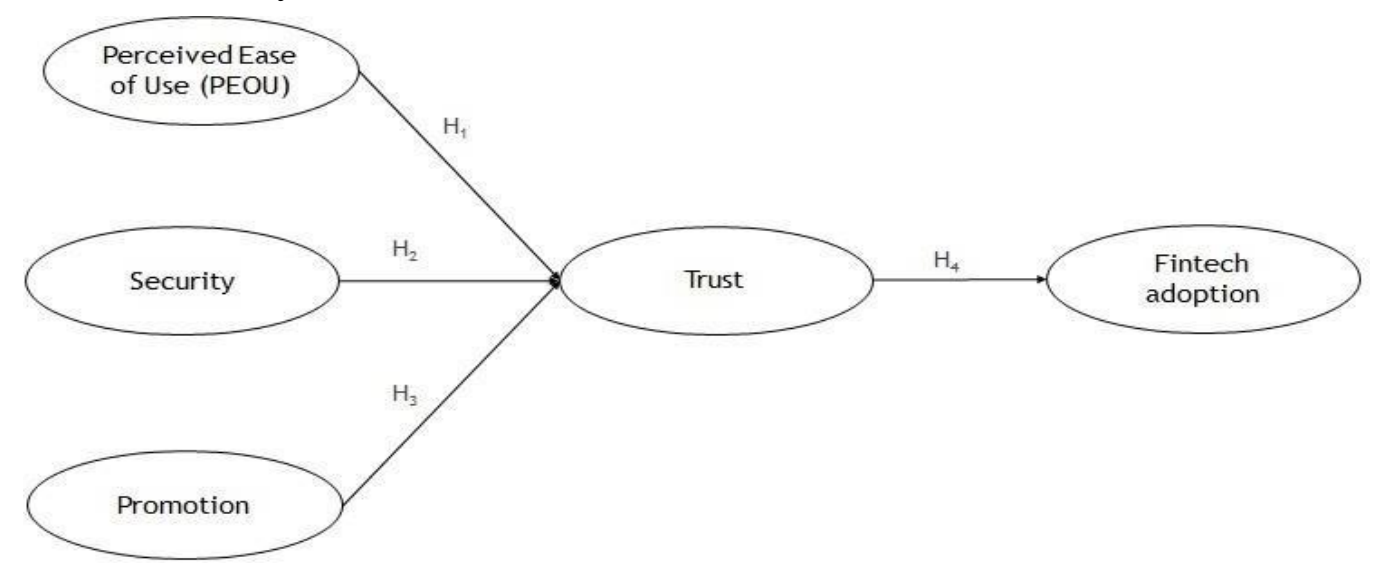

Figure 1 Research model

The hypotheses tested in this research were as follows.

H1 : Perceived ease of use affects significantly on customer trust in fintech.

$\mathrm{H} 2$ : Security affects significantly on customer trust in fintech.

H3 : Promotion affects significantly on customer trust in fintech.

$\mathrm{H} 4$ : Customer trust in fintech affects significantly on fintech adoption 


\section{Findings}

\section{Validity Testing}

The validity test of the instrument (indicator) was conducted to measure the validity of an instrument (indicator). Validity testing was carried out through validity test Discriminant outer loading and cross-loading, in which an indicator is reliable/valid if it has a loading factor value $>0.70$ (Hair, Hult, \& Ringle, 2014). The test results can be seen in Table 1.

Table 1 Loading and Cross Loading

\begin{tabular}{ccccccc}
\hline Indicators & $\begin{array}{c}\text { Fintech } \\
\text { Adoption }\end{array}$ & PEOU & Promotion & Security & Trust & $\begin{array}{l}\text { Conclusion } \\
\text { s })\end{array}$ \\
\hline FA1 & $\mathbf{0 . 7 9 4}$ & 0.621 & 0.291 & 0.240 & 0.342 & Valid \\
FA2 & $\mathbf{0 . 9 4 3}$ & 0.672 & 0.506 & 0.301 & 0.491 & Valid \\
FA3 & $\mathbf{0 . 9 3 9}$ & 0.573 & 0.448 & 0.284 & 0.528 & Valid \\
PEOU1 & 0.565 & $\mathbf{0 . 7 8 2}$ & 0.314 & 0.459 & 0.346 & Valid \\
PEOU2 & 0.612 & $\mathbf{0 . 8 8 2}$ & 0.395 & 0.381 & 0.429 & Valid \\
PEOU3 & 0.590 & $\mathbf{0 . 8 5 3}$ & 0.318 & 0.391 & 0.273 & Valid \\
PEOU4 & 0.419 & $\mathbf{0 . 7 0 8}$ & 0.373 & 0.270 & 0.267 & Valid \\
PEOU5 & 0.497 & $\mathbf{0 . 7 1 0}$ & 0.317 & 0.215 & 0.440 & Valid \\
Prom1 & 0.479 & 0.448 & $\mathbf{0 . 8 5 1}$ & 0.313 & 0.426 & Valid \\
Prom2 & 0.437 & 0.468 & $\mathbf{0 . 8 4 2}$ & 0.291 & 0.340 & Valid \\
Prom3 & 0.323 & 0.208 & $\mathbf{0 . 7 6 8}$ & 0.057 & 0.272 & Valid \\
Prom4 & 0.235 & 0.210 & $\mathbf{0 . 7 5 8}$ & 0.071 & 0.265 & Valid \\
Sec1 & 0.229 & 0.290 & 0.173 & $\mathbf{0 . 8 3 9}$ & 0.180 & Valid \\
Sec2 & 0.270 & 0.419 & 0.270 & $\mathbf{0 . 9 2 4}$ & 0.381 & Valid \\
Sec3 & 0.299 & 0.360 & 0.159 & $\mathbf{0 . 7 8 3}$ & 0.195 & Valid \\
Trust1 & 0.420 & 0.383 & 0.376 & 0.249 & $\mathbf{0 . 8 8 8}$ & Valid \\
Trust2 & 0.524 & 0.479 & 0.392 & 0.327 & $\mathbf{0 . 9 5 6}$ & Valid \\
Trust3 & 0.474 & 0.411 & 0.381 & 0.323 & $\mathbf{0 . 9 0 7}$ & Valid \\
\hline PEOU $\rightarrow$ Perid & & & & & \\
\end{tabular}

PEOU $\rightarrow$ Perceived ease of use; *) valid if loading factor value $>0.70$

Average Variance Extracted (AVE) in which data collection instruments are considered valid if the calculation results of the variables are $>0.50$. The test results can be seen in Table 2.

Table 2 Average Variance Extracted (AVE)

\begin{tabular}{lcr}
\hline Variables & AVE & Conclusions *) \\
\hline Fintech Adoption & 0.800 & Valid \\
Perceived Ease of Use & 0.624 & Valid \\
Promotion & 0.649 & Valid \\
Security & 0.723 & Valid \\
Trust & 0.842 & Valid \\
\hline *) valid if p-value $>0.50$ & &
\end{tabular}




\section{Reliability Testing}

Reliability tests were carried out to measure the level of consistency and stability of research instruments in measuring a concept or construct. Reliability testing was carried out by testing (1) Composite Reliability. (2) Cronbach's Alpha. The test results can be seen in Table 3 . A constructed variable is reliable if it has a reliability number of each construct for the test valued $>0.7$ (Winoto \& Wahyoedi, 2017). From the value of composite reliability and Cronbach's Alpha, it can be seen that each had a value above 0.7 ; thus, the research variables had fulfilled the rule of reliability.

Table 3 Composite reliability and Cronbach's alpha

\begin{tabular}{lrrr}
\hline Variable & $\begin{array}{r}\text { Composite } \\
\text { Reliability } * \text { ) }\end{array}$ & $\begin{array}{r}\text { Cronbach's } \\
\text { Alpha *) }\end{array}$ & Status \\
\hline Fintech Adoption & 0.923 & 0.875 & Reliable \\
Perceived Ease of Use & 0.892 & 0.848 & Reliable \\
Promotion & 0.881 & 0.824 & Reliable \\
Security & 0.886 & 0.821 & Reliable \\
Trust & 0.941 & 0.906 & Reliable \\
\hline
\end{tabular}

Note : reliable if the value $>0.70$

Goodness of Fit (GOF) test or the model feasibility test was used to measure the accuracy of the regression function in estimating the actual values. GOF can be measured using Q-square $\left(\mathrm{Q}^{2}\right)$ obtained from endogenous latent $\mathrm{R}$-square $\left(\mathrm{R}^{2}\right)$ variables with the same interpretation as regression. Based on the calculation results of this research, $\mathrm{R}^{2}$ values were obtained as follows (Table 4).

Table 4. Value of $\mathrm{R}^{2}$

\begin{tabular}{lr}
\hline Variables & R Square \\
\hline Fintech Adoption & 0.268 \\
Trust & 0.288 \\
\hline
\end{tabular}

Table 4 highlights that $\mathrm{R}^{2}$ for fintech adoption was 0.268 , while $\mathrm{R}^{2}$ for trust was 0.288 . The GOF test in this research is as follows.

$$
\begin{gathered}
\mathrm{Q}^{2}=1-(1-0.268)(1-0.288) \mathrm{Q}^{2}=1-(0.732 \times 0.712) \\
\mathrm{Q}^{2}=0.479
\end{gathered}
$$

$\mathrm{Q}^{2}$ of this research model was $0.479>0$, indicating that the observed values have been reconstructed properly so that the model has predictive relevance.

The effect of perceived ease of use on trust was 0.295 , with a p-value of 0.007 . Meanwhile, the effect of security on trust was 0.138 , with a p-value of 0.129 . The effect of promotion on trust was 0.254 , with a p-value of 0.006 . Thus, the most dominant variable influencing trust as perceived ease of use. This means that the increase in perceived ease of use will increase trust in fintech. Furthermore, the effect of trust on fintech adoption was 0.518, with a p-value of 0.000 (Figure 2). 


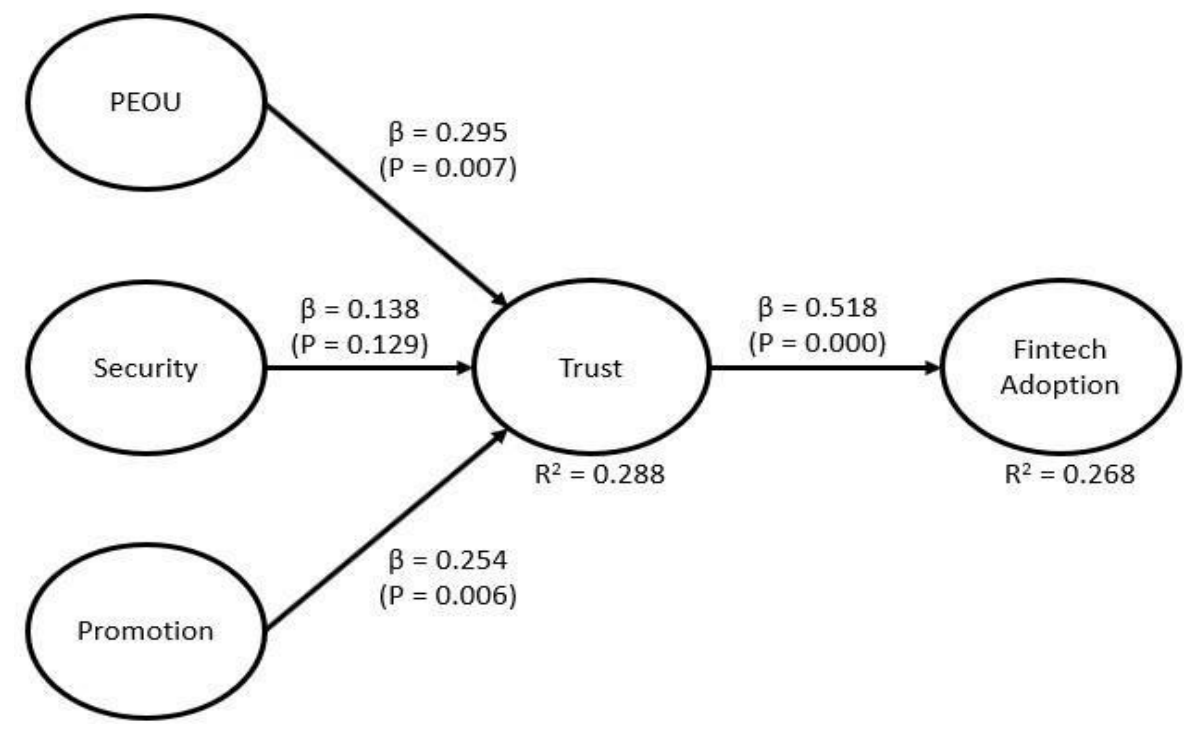

Figure 2. SEM Result

Table 5 Hypothesis testing

\begin{tabular}{llrrr}
\hline Hypothesis & \multicolumn{1}{c}{ Effect } & Coefficient & p-value & Remarks \\
\hline H1 & PEOU $\rightarrow$ Trust & 0.295 & $0.007^{*}$ & Significant \\
H2 & Security $\rightarrow$ Trust & 0.138 & 0.129 & Not-Significant \\
H3 & Promotion $\rightarrow$ Trust & 0.254 & $0.006^{*}$ & Significant \\
H4 & Trust $\rightarrow$ Fintech Adoption & 0.518 & $0.000^{*}$ & Significant \\
\hline
\end{tabular}

Note: PEOU is Perceived Ease of Use; *significant at $<0.01$

\section{H1: Perceived ease of use affected customer trust on fintech}

From Table 5 it can be seen that The effect of perceived ease of use (PEOU) on trust was 0.295 with $\mathrm{p}$-value $=0.007$ was less than the significance value of 0.05 ; as a result, the hypothesis was accepted, indicating that perceived ease of use (PEOU) had a positive effect on customer trust. This means that if there is an increase in PEOU, it will have an impact on the increased customer trust in fintech.

\section{H2 : Security affected customer trust on fintech}

Table 5 shows the effect of security on trust was 0.129 with p-value $=0.129$ was greater than the significance value of 0.05 ; therefore, the hypothesis was rejected, showing that security had a positive effect on customer trust. Nonetheless, there was not enough statistical evidence to support this hypothesis.

\section{H3 : Promotion affected customer trust on fintech}

Table 5 shows that the effect of promotion on customer trust was 0.254 with pvalue $=0.006$ was less than the significance value of 0.05 ; as a result, the hypothesis was accepted. It indicates that promotion had a positive effect on customer trust. This means that if there is an increase in promotion, it will have an impact on the increase of customer trust in fintech. 


\section{H4 : Customer trust in fintech affected fintech adoption}

Table 5, it can be seen that the effect of promotion on customer trust was 0.518 with $p$-value $=0.000$ was less than the significance value of 0.05 ; hence, the hypothesis was accepted. It was indicating that customer trust had a positive effect on fintech adoption. This means that if there is an increase in customer trust, it will have an impact on the increase of customer trust in fintech adoption.

\section{Discussions}

This research found that perceived ease of use (PEOU) had a positive effect on customer trust. When interacting with other parties, people consciously capture information and use existing information, such as appearance, to assess how trustworthy the party is, or in this context, a service provider or a product. If a website developer institution strives to make the website easier to use with easier navigation for users to understand, it can also be interpreted that the institution is committed to maintaining relationships with customers. This commitment and sincerity give customers confidence that the company is indeed sincere in doing business without any intention of behaving opportunistically so that it can build customer trust. According to Pavlou \& Gefen (2004) stated that when interacting (with other parties), people consciously capture information and use existing information such as appearance to assess how trustworthy the party is, or in this context, the service provider or the product. If a website developer institution strives to make the website easier to use with easier navigation for users to understand, it can also be interpreted that the institution is committed to maintaining relationships with customers, so as to build the trust of its users.

This finding was confirmed by Chandra et al. (2018), stating that the perceived ease of use affected customer trust of GO-Pay mobile payment. The easier it is to use, the higher the trust of the consumers, thus making it easier for them to pay drivers and merchants. This finding also strengthens the research results of Gefen, Karahanna, and Straub (2003) in electronic commerce, stating that PEOU had a positive effect on customer trust on fintech. Hu et al. (2019), in their research on fintech services in China, also found that PEOU had a positive effect on customer trust in fintech. According to Pavlou and Gefen (2004) stated that when interacting (with other parties), people consciously capture information and use existing information such as appearance to assess how trustworthy the party is, or in this context, the service provider or the product. If a website developer institution strives to make the website easier to use with easier navigation for users to understand, it can also be interpreted that the institution is committed to maintaining relationships with customers, so as to build the trust of its users.

This study found no enough statistical evidence to support that data security affected customer trust in fintech. This finding was in contrast to the results of the studies conducted by Grabosky et al., (2001); Kinasih and Albari, (2012), and Stewart, and Jürjens, (2018) stating that internet-based financial transactions are built from a trusted transaction process in which businesses must create an atmosphere that is able to make potential customers feel safe, comfortable, and confident to perform transactions via the internet, indicating that when users feel safe while using technology, their trust will be built. 
The inconsistency of the research results with some previous studies may be caused by several things. A study conducted by (Stewart \& Jürjens, 2018) in Germany revealed that the growth of fintech users in the country per year was fairly slow. There is also another research stating that $82 \%$ of Germans were reluctant about fintech because the priority of German society was the security of personal data. According to an article on statistica.com, 2015, German society is very protective of its personal data such as health records, credit cards, assets, and personal identity compared to those of the United States.

Hence, it can be concluded that an individual who has never tried something will have a higher level of anxiety than those who have done it so that it will have an impact on the trust level. This is different from the conditions in Indonesia, where the internet users from 2017 reached more than half the population. This shows that the level of trust of Indonesian society towards new technology is greater than that of German's. Moreover, the monitoring of fintech regulators in Indonesia also found that the role of security has not yet been the determinant factor in building customer trust in fintech.

In Sakuku case, security has no significant effects on trust, possibly because the community's trust has been built on the image of Bank X as the organizer of Sakuku. Bank X, the largest private bank in Indonesia, has an excellent reputation in the public eye so that Bank $\mathrm{X}$ has gained public trust in solving problems in banking transactions. For instance, there were some reports that Bank X customer balances were lost in accounts allegedly due to Bank X's negligence in maintaining internal security systems. The news was immediately handled by Bank X, and it carried out an investigation and follow-ups that were appropriate and fast. Therefore, those cases were immediately resolved. This creates a positive image in the public eye that Bank $\mathrm{X}$ is always at the forefront in following up on issues related to security, which can be seen from the vast number of people who remain loyal customers of Bank X.

Even though, the security aspect is important in an information system. Data security in the digitalization era full of uncertainty due to rapid technological developments is closely related to customer trust, especially in the financial sector. The scope of data security is reasonably broad, i.e., and it can be in the forms of equipment used to collect and store data, transmission processes, including accuracy, legitimacy, benefits, and ownership. From a more critical perspective, these various definitions require further analysis in which data security cannot be considered as a product of technology, rather it is considered as an entire process (Stewart \& Jürjens, 2018).

Meanwhile according to Bank Indonesia, Fintech, in general, consists of four major types of industries that is firstly, crowdfunding and peer-to-peer lending it's a marketplace for the capital seekers and investors in the field of loans to meet where the provider only provides facilities that allow lenders and borrowers to carry out the lending and borrowing process online. Second, market aggregator it's a portal that collects various information on financial service options to be presented to users. The information can then be compared to determine the best financial products for users, so they can learn the advantages and disadvantages of each product and choose the most appropriate product. Third, risk management and investment it's financial planning in digital form. This type of fintech helps users to analyze their personal financial situation, as well as to do financial planning (budgeting) easily and quickly. Four, payment, clearing, and settlement it's a payment system service organized by both the banking industry and B.I. This portal simplifies the process of online transactions. E- 
wallet and payment gateway services are also included in this type. Sakuku is also an application-based e-wallet product.

This research stated that promotion affected customer trust in fintech. This means that the greater the promotion felt by the public, the greater the customer trust gained on fintech products. This supports the research of Tariq (2014) regarding promotion, which can be interpreted as a company's effort to communicate with customers about the products being marketed. Promotion is one aspect of the marketing mix. The context of promotion by Fintech companies refers to marketing communications carried out through personal selling, advertising, direct marketing, public relations, sales promotions, and sponsorship. The fintech payments in Indonesia, such as Sakuku, OVO, GoPay, and others, are always launched along with various lucrative advertisements/promotions for its users. These advertisements are very aggressively launched in the forms of convenience publications, enriched features, and massive discounts. These promotions provide a booster for the company to increase the number of users of its fintech brand.

Promotion can also be interpreted as an effort of the company to communicate with customers about products marketed (Tariq, 2014; Farida, Tarmiz, \& November 2016). Promotions can include advertisement, discounts, gifts/souvenirs, stalls in various shopping centers. The more publicity the company issues on its products, the higher the number of its users, which will have an impact on increasing customer trust.

As we can see, the number of merchants receiving fintech payment types in various shopping centers in Indonesia has continued growing. This means that the promotion has a positive effect on building customer trust. Warjiyono et al. (2019) conducted research on Fintech users in Tegal City, especially the Ovo application, since it currently has a very massive market and promotion. They found that users choosing the Fintech application generally consider convenience, security, transaction suitability, convenience, and cashback. The problem is that the user's trust in fintech is still low.

In regards to the financial sector, trust is the most fundamental factor. In a risky condition, trust is required so that the parties involved are willing to take risks. Trust helps users to overcome the concerns they face and encourages them to adopt the product. Junger and Mietzner (2019) demonstrated that household levels of trust and comfort with new technology, financial literacy, and overall transparency influence its tendency to switch to FinTech. In particular, households with low levels of trust, good financial education and a preference for transparency were characterized by a higher likelihood of adopting FinTech. Trust can be formed through three dimensions that is, first ability it refers to competencies and characteristics. Second, benevolence its a willingness to provide mutual satisfaction to both parties. Third, integrity it's relates to how the business is conducted, whether the information provided to customers is true and in accordance with facts or not.

The findings of this study indicate that trust influenced customer decision to use a fintech brand (Fintech adoption). The higher the customers' trust on fintech, the higher their possibility in using fintech. This finding is in accordance with $\mathrm{CaO}, \mathrm{Yu}, \mathrm{Gong}$ and Adeel (2018) in their fintech research in China. They found that that the trust transfer process positively influences the continuance intention of mobile payment. Also this finding in line with Simanjuntak, Putri, Yuliati and Sabri (2020) that turs influence the consumer to repurchase. According to Shao, Zhang, Li and Guo (2019) found that customers' trust, in turn, is negatively associated with perceived risk 
and positively associated with continuance intention among Alipay and Wechat pay users in China.

Since this research was only conducted in Jakarta, it cannot be generalized to Indonesia. Pandemic conditions bring limitations to collecting samples throughout Indonesia. This study only took the Bank X customers in Jakarta as analysis unit, so the results of this study could not be used to generalize with other financial institutions. This sampling is the limitation of the researchers in reaching a large sample. Meanwhile, the variables involved in this study were only analyzed through causalities analysis. It would be better to use other variables for moderation or mediation analysis by involving demographic variables (Carlin, Olafsson, \& Pagel, 2019). Other variables that can be consider to be studied are perceived technology, perceived risk, and institution-based trust (Yuliati, Dradjat, \& Simanjuntak, 2020), emotions (Simanjuntak, Nur, Sartono, \& Sabri, 2020). Limitations during the Covid-19 pandemic make it impossible to explore moderating and mediating variables.

\section{Conclusion and Recommendation}

\section{Conclusion}

Based on the results of hypothesis testing where PEOU had a positive and significant effect on trust, the increasing convenience offered by a fintech product will increase customer trust in the product. Improvements to the convenience provided by the company will increase customer trust. As for data security, based on the hypothesis testing, there was no sufficient evidence to show that it had a significant effect on trust, indicating that the more secured fintech product may not necessarily increase the customer trust. In addition, the results of hypothesis testing indicate that promotion had a significant and positive effect on customer trust, showing that the greater the promotion felt by the public, the greater their trust on a fintech product, and an increase in promotions given by the company will increase customer trust. From the determinant variables of trust, PEOU is the variable that has the most dominant influence on trust.

The results of this research indicate that customer trust had a significant and positive effect on the use of fintech (fintech adoption), indicating that the greater the customer trust on a fintech brand, the greater the opportunity for users to adopt or use it. An Increase in customer trust will gain a greater number of fintech users.

\section{Recommendation}

The ease of features includes increasing integration between platforms and promotions and providing its own ecosystem that stimulates users to continue using Sakuku in daily life. For instance, Go-pay and OVO are integrated with Gojek and Grab, where the needs of millennials who currently have high mobility are accommodated by the platforms by using Gojek and Grab as financial media. Meanwhile, increasing the Security of Sakuku can be an added value for its users. In this research, security had no significant effect on trust, and this is contrary to previous studies. The researchers can then conduct research on the direct impact of security on fintech adoption to examine whether security affects fintech adoption directly without going through trust.

In accordance with the results of this research, the variables and models used by researchers can only explain $48 \%$ of the variables that affect fintech adoption. Further 
studies can examine the direct impacts of exogenous variables in this research on fintech adoption's endogenous variables:

- The impact of perceived ease of use on fintech adoption.

- The direct impact of security on fintech adoption.

- The direct impact of promotion on fintech adoption.

Because the $\mathrm{R}^{2}$ value of this study was still quite low, it caused the $\mathrm{Q}^{2}$ value to be small, indicating that there are many other key variables that determine fintech adoption that was not covered in this research. Further research can add and look for those other variables.

\section{References}

Abdullatif, Z., Purnaningsih, N., \& Simanjuntak, M. (2020). Analysis Of Willingness To Lend In Peer-To-Peer Lending Applications; RJOAS, 5(101): 13-22. Russian Journal of Agricultural and Socio-Economic Sciences. https://doi.org/10.18551/rjoas.2020-05.02.

Anjelina, A. (2018). Consumer perception on e-money usage. Journal of Applied Managerial Accounting, 2(2), 219-231. https://doi.org/10.30871/jama.v2i2.934

Ardela, F. (2017). Tengok dulu perkembangan fintech di Indonesia. Retrieved, from https://www.finansialku.com/

[BI] Bank Indonesia. (2018). Inclusive Finance in Indonesia - Central Bank of the Republic of Indonesia. Retrieved May 4, 2019, from https://www.bi.go.id/

Cao, X., Yu, L., Liu, Z., Gong, M., \& Adeel, L. (2018). Understanding mobile payment users' continuance intention: a trust transfer perspective. Internet Research, 8(2), 456-476. https://doi.org/10.1108/IntR-11-2016-0359

Carlin, B., Olafsson, A., \& Pagel, M. (2019). FinTech Adoption Across Generations: Financial Fitness in the Information Age. Paper presented at AEA Annual Meeting 2019, Atlanta, United States.

Chandra, Y. U., Kristin, D. M., Suhartono, J., Sutarto, F. S., \& Sung, M. (2019). Analysis of determinant factors of user acceptance of mobile payment system in indonesia (a case study of go-pay mobile payment). Proceedings of 2018 International Conference on Information Management and Technology, ICIMTech 20188 November 2018, Article number 8528182, Pages 454-459

Chau, K .P. Y., \& Lai, K. V. S. (2003). An empirical investigation of the determinants of user acceptance of internet banking. Journal of Organizational Computing and Electronic Commerce, 13(2), 123-145.

Davis, F. D. (1989). Perceived usefulness, perceived ease of use, and user acceptance of information technology. MIS Quarterly, 13(3), 319-340. DOI: 10.2307/249008

Farida, I., Tarmzi, A., \& November, Y. (2016). Analysis of the effect of 7p marketing mixed on customer satisfaction online gojek user. Journal of Management and Business Research, 1(1), 31-40. ISSN: 2527-7502.

Fost, J., (2020). The Economic Forces Driving Fintech Adoption Across Countries. Bank for International Settlements. Retrieved from https://www.bis.org/publ/cmtpubl.htm?m=5\%7C28

Gefen, D., Karahanna, E., \& Straub, D. W. (2003). Trust and TAM in online shopping: an integrated model. MIS Quarterly, 27(1), 51-90. DOI: 10.2307/30036519

Grabosky, P., Duffield, G., \& Graycar, A. (2001). Red Flags of Fraud in crime and criminal justice. 
Hair, J. F., Hult, G. T. M., \& Ringle, C. M. (2014). A primer on partial least squares structural equation modelling (PLS-SEM). Thousand Oaks: Sage.

Heryani, I.I.P., Simanjuntak, M., \& Maulana, A. (2020). Perilaku penggunaan internet banking sebagai alat transaksi finansial behavioral usage of internet banking as financial transaction tool. Jurnal Aplikasi Manajemen dan Bisnis, 6 (1) : 86-95. http://dx.doi.org/10.17358/jabm.6.1.86

Hsu, C. L, \& Lin, J. C. C (2015). Effect of perceived value and social influences on mobile app stickiness and in-app purchase intention. Technological Forecasting and Social Change, Elsevier 108, 42-53. DOI: 10.1016/j.techfore.2016.04.012. https://doi.org/10.1207/S15327744JOCE1302_3

https://ssrn.com/abstract=3368133 or http://dx.doi.org/10.2139/ssrn.3368133

https://www.aeaweb.org/conference/2019/preliminary/paper/rNa4i8Y3

Hu, Z., Ding, S., Li, S., Chen, L., Yang, S., (2019). Adoption intention of fintech services for bank users: An empirical examination with an extended technology acceptance model. Symmetry, 11(3), 340. DOI: 10.3390/sym11030340

IDN Financials. (2019). Morgan Stanley: R.I.'s digital payments may reach US\$ 50 billion by $2027-$ IDN Financials. Retrieved, from https://www.idnfinancials.com

Junger, M., \& Mietzner, M. (2019). Banking Goes Digital: The Adoption of FinTech Services by German Households. Retrieved from SSRN

Kepuasan dan Kepercayaan Konsumen Online. Jurnal Siasat Bisnis, 16(1), 25-38.

Kinasih, B. S., \& Albari, A. (2012). Pengaruh Persepsi Keamanan dan Privasi terhadap

Mention, L. A. (2019). The future of fintech. Research-Technology Management, 62(4), 59-63. https://doi.org/10.1080/08956308.2019.1613123

Meyliana, M. And Fernando, E. (2019). The Influence of Perceived Risk and Trust in Adoption of FinTech Services in Indonesia. CommIT, 13 (1), 31-37

Pavlou, P. A., \& Gefen, D. (2004). Building effective online marketplaces with institutionbased trust. Information Systems Research, 15(1), 37-59. https://doi.org/10.1287/isre.1040.0015

Raman, A., \& Annamalai, V. (2011). Web services and e-shopping decision: a study on Malaysia e-consumer. International Journal of Computer Applications, 2, 54-60.

Shao, Z., Zhang, L., Li, X., \& Guo, Y. (2019). Antecedents of trust and continuance intention in mobile payment platforms: The moderating effect of gender. Electronic Commerce Research and Applications, 33, January-February. doi: https://doi.org/10.1016/j.elerap.2018.100823

Simanjuntak, M., Putri, N. E., Yuliati, L. N., \& Sabri, M. F. 2020. Enhancing customer retention using customer relationship management approach in car loan bussiness. $\begin{array}{llll}\text { Cogent Business \& } & \text { Management, }\end{array}$ https://doi.org/10.1080/23311975.2020.1738200

Simanjuntak, M., Nur, H.R., Sartono, B., Sabri, M.F. (2020). A general structural equation model of the emotions and repurchase intention in modern retail. Management Science Letters. 10 (4) : 801-814. DOI: 10.5267/j.msl.2019.10.017

Stewart, H., \& Jürjens, J. (2018). Data security and consumer trust in FinTech innovation in Germany. Information and Computer Security, 26(1), 109-128. ISSN: 20564961. https://doi.org/10.1108/ICS-06-2017-0039

Tariq, K. M. (2014). The concept of marketing mix and its elements. International Journal of Information, Business and Management, 6(2), 95-107. ISSN 2076- 9202. 
Tri, R. (2019, October 4). Losing to gopay and ovo, debit card transactions decline. Tempo.co. Retrived from https://bisnis.tempo.co/read/1255596/kalah-dengangopay-dan-ovo-transaksi-kartu-debit-merosot/full\&view=ok

Wahyoedi, S., (2017). The effect of religiosity, service quality, and trust on customer loyalty in islamic banking in Bogor Indonesia. International Review of Management and Business Research, 6(1), 331-340.

Warjiyono, A. S., Fandhilah, H. N., Faqih, H., \& Liesnaningsih. (2019). The Sentiment Analysis of Fintech Users Using Support Vector Machine and Particle Swarm Optimization Method. 7th International Conference on Cyber and I.T. Service Management, CITSM.

Widiastuti, I. (2018). Principles of Bank Confidentiality on customer data in related financial technology, Justitia Jurnal Hukum, 2(2), 390-402. E-ISSN: 25796380.

Widyastuti, D. A., \& Anggraeni, K. (2017). Effect of Ease (Perceives Ease of Use) on ReInterest in Application Use. Universitas Bakrie (Unpublish). Retrieved from http://repository.bakrie.ac.id/id/eprint/1286.

Yuliati, L. N., Dradjat, H. A., \& Simanjuntak, M. (2020). Online bike: Role of perceived technology, perceived risk, and institution-based trust on service usage via online trust. Cogent Business \& Management, 7(1), 1798067. https://doi.org/10.1080/23311975.2020.1798067 